\title{
Criticizing and Investigating the Theory of Royal Ring in Parthian and Sassanid Reliefs
}

\section{Criticando e investigando la teoría del Anillo Real en los relieves Partianos y Sasánidas}

\author{
Reza Azadijou 1 \\ ${ }^{1}$ MA graduate, archaeology department, Golestan Higher Education \\ Institution, Iran, Email: rezaazadijou@yahoo.com
}

Enviado: 27 de junio de 2019

Aceptado para publicar: 30 de julio de 2019

Publicado: 8 de agosto de 2019

\begin{abstract}
There is an outstanding action displayed in a great many of the scenes of the inscriptions on the containers, seals and coins from various archaeological eras, including those of Parthians and Sassanid. The action is defined with it being given a ring which resides in various scenes and inscriptions featuring different ornamentation as well as in different individuals' hands. The majority of the scenes depict the carrying of the ring in hands between two personalities: Ahura Mazda and the king, the goddess and the king, the queen and satrap, the queen and the king, the king and the successor and the goddess and the goddess. It is worth mentioning that the ring is only in the hand of one figure with no counterpart in some of the science. The archaeologists doing research in this regard, including Roman Ghirshman, Luis Vandenberg, Robert Hertsfeld, John Kurtis, Sayyed Rasoul Musavi, Haji Ali Akbar Sarafraz and others, have all pointed to one single subject indicating that the intended ring is a sign of granting the kingship ring, sultanate or power with the explanation being that the ring gifted from the God to the king indicates His granting of power and sultanate to the king and/or the granting of the ring by the king to the satrap is indicative of his gifting of power to satrap hence legitimizing him. The present study aims at criticizing the theory and determining the semantic and symbolic load of the ring role as well as the ring's different use cases in the various scenes. According to the researches done by the author in the present study, the granting of the ring with the objective of transferring the power or sultanate cannot perfectly convey the content of the inscriptions and many contradictions come about in various scenes considering such a semantic load. That is because the symbolic load of the ring is defined based on a deductive reasoning in doing so. It was concluded in an investigation of the extant inscriptions and recognition of the content of each work that the ring can be an indicator of the unification between two opposing personalities hence reflective of the unity and association in religious and political terms in such a manner that the carrying of the ring in hand between the God and the king showcases the unification between these two personalities and it can be stated that both personalities exemplify their own specific procedures. King stands for government and Ahura Mazda models religion and, considering that both these figures have taken the ring of unification in their hands, it is illustrative of the unification between the government or sultanate with religion or creed and a supernatural power. It is noteworthy that there is a defining of a special subject in every scene wherein unification has been demonstrated. This underlying subject has been classified into three sets by the author: 1) established unification; 2) unification in progress; 3) unification request. The present study introduces scenes of the inscriptions with ring of unification following which the issue will be perfectly analyzed and interpreted. The current research paper is a descriptive-analytical research that has been conducted based on library method.
\end{abstract}

Keywords: ring of power, ring of unification, criticism, relief, Parthians, Sassanid.

Hay una acción sobresaliente que se muestra en muchas de las escenas de las inscripciones en los contenedores, sellos y monedas de varias épocas arqueológicas, incluidas las de los partos y sasánidas. La acción se define con un anillo que reside en varias escenas e inscripciones con diferentes ornamentos, así como en las manos de diferentes personas. La mayoría de las escenas muestran el porte del anillo en manos entre dos personalidades: Ahura Mazda y el rey, la diosa y el rey, la reina y el sátrapa, la reina y el rey, el rey y el sucesor y la diosa y el rey. diosa. Vale la pena mencionar que el anillo solo está en la mano de una figura sin contraparte en algunas de las ciencias. Los arqueólogos que investigan a este respecto, incluidos Roman Ghirshman, Luis Vandenberg, Robert Hertsfeld, John Kurtis, Sayyed Rasoul Musavi, Haji Ali Akbar Sarafraz y otros, han señalado un solo tema que indica que el anillo previsto es un signo de concesión de anillo de reinado, sultanato o poder con la explicación de que el anillo regalado del dios al rey indica que su concesión de poder y sultanato al rey y / o la concesión del anillo por el rey al sátrapa es indicativo de su donación de poder de sátrapa por lo tanto legitimándolo. El presente estudio tiene como objetivo criticar la teoría y determinar la carga semántica y simbólica del papel del anillo, así como los diferentes casos de uso del anillo en las diversas escenas. Según las investigaciones realizadas por el autor en el presente estudio, la concesión del anillo con el objetivo de transferir el poder o el sultanato no puede transmitir perfectamente el contenido de las inscripciones y muchas contradicciones surgen en varias escenas considerando tal carga semántica. Esto se debe a que la carga simbólica del anillo se define en base a un razonamiento deductivo al hacerlo. Se concluyó en una investigación de las inscripciones existentes y el reconocimiento del contenido de cada trabajo que el anillo puede ser un indicador de la unificación entre dos personalidades opuestas, por lo tanto, refleja la unidad y la asociación en términos religiosos y políticos de tal manera que llevar el anillo en la mano entre el Dios y el rey muestra la unificación entre estas dos personalidades y se puede afirmar que ambas personalidades ejemplifican sus propios procedimientos específicos. King defiende el gobierno y Ahura Mazda modela la religión y, considerando que ambas figuras han tomado el anillo de la unificación en sus manos, es ilustrativo de la unificación entre el gobierno o el sultanato con la religión o el credo y un poder sobrenatural. Es de destacar que hay una definición de un tema especial en cada escena en la que se ha demostrado la unificación. Este tema subyacente ha sido clasificado en tres conjuntos por el autor: 1) unificación establecida; 2) unificación en progreso; 3) solicitud de unificación. El presente estudio presenta escenas de las inscripciones con un anillo de unificación, luego de lo cual el tema será perfectamente analizado e interpretado. El trabajo de investigación actual es una investigación descriptiva-analítica que se ha realizado en base al método de la biblioteca.

Palabras clave: anillo de poder, anillo de unificación, crítica, alivio, Partia, Sasánida. 


\section{Introduction and Study Background}

Many archaeological researchers, including Roman Ghirshman, Stein, Robert Hertsfeld, John Kurtis, Lukonin, Luis Vandenberg, Musavi Haji, Shapour Shahbazi, Sarfaraz and others have studied the various scenes of the works remained from the archaeological eras and analyzed the subjects, personalities, signs and symbols introduced in narrations. All of these archaeologists' ideas and notions have been dealt with herein in terms of the subjects related to the present study. The following sections provide an overview of the ideas by some researchers:

1. Professor Ghirshman's opinions regarding some scenes of Rustam Inscription: in Rustam inscription, the king is seen performing religious rites before Ahura Mazda on top of his resting place around a fire pot. Here, the inscription essentially portrays a religious aspect but the same idea does not hold for Takht-e-Jamshid and the thought that is concealed in the Takht-e-Jamshid inscription displaying the same god must be substantially serving political purposes and the texts on Darius petroglyphs convey this same meaning and it is frequently rendered as bearing the idea of association and pact between the king and his god encapsulated in the depiction of a kingship ring as a heavenly gift and a manifestation of the king power. Accepting this rendering makes us believe that the reliefs in Takht-e-Jamshid are the sources of a series of real scenes of crown abdication (Ghirshman, 1991: 262).

2. Shahriyar's Acceptance of a Ring from the God and the Goddesses: based on their beliefs, the ring is a symbol of the magnificence of their God and its granting by a human to the king contradicts their religious beliefs. The ring features special characteristics meaning that there is attached a long and waving tape thereto. The tape has been repeatedly depicted in various forms in the reliefs on the uniforms of the officers and commanders (Javadi, Avarzamani, 2009: 65).

3. Depicting the Divinity of the King's Position in Sassanid Era's Reliefs: the ring is sometimes shown to have been granted by Ahura Mazda and sometimes by Anahita to the king (Musavi Haji, 1995: 16).

4. The king does not directly take the sultanate ring from the hands of a material human of the same kind as his in any of the Sassanid reliefs. Of course, there are some individuals on some reliefs that have rings in their hands stretched towards the king and are presenting them to the king but the king has not taken the ring in his hands in any of them. Moreover, the aforementioned rings have no ribbons. In other words, it is only in one case in all the artistic works remained from this era including the reliefs, beakers, coins, seals and other relics that the Sassanid king directly takes the sultanate ring in his hand and that is the case wherein the figure presenting the ring is one of the goddesses otherwise the king is improbable to have taken a ring offered by another person of his kind in hand. Even if such a case is observed, the author is sure that the ring lacks long and waving tapes (Musavi Haji, 1995: 91).

5. God's Granting of Crown in Rustam Inscription (Image 1): the inscription seems to have better portrayed Ardashīr's victory over Parthians in appearance terms. The Parthian king is shown fallen beneath Ardashīr's horse and the evil, as the manifestation of darkness and wrongdoing is shown beneath Ahura Mazda's horse. The inscription signifies the anti-Parthian spirits of the Sassanid King and the victory and splendor of the Zoroastrian rituals. Both these thoughts have been clearly followed in the book sources but none of the aforesaid thoughts have emerged at the same time with Ardashīr's enthroning so the progress stream of these thoughts can be figured out to some extent (Lukonin, 2005; Courtney, 2018).
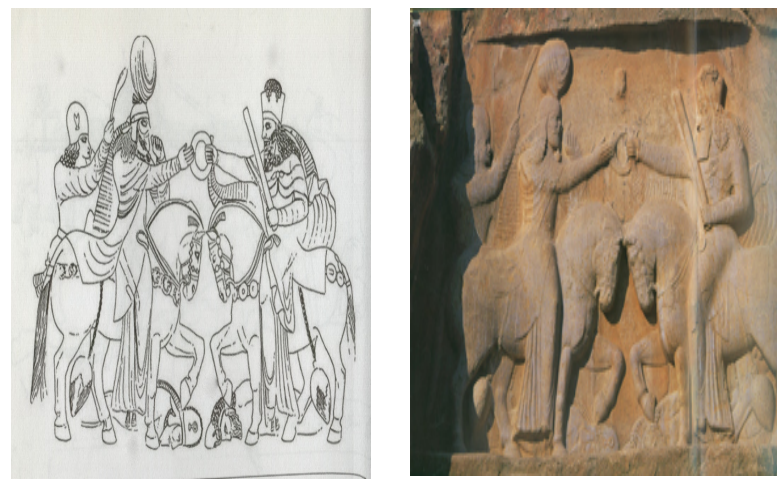

Figure 1. Mohammadifar and Amini (2015: 217) (article.tebyan.net)

6. In a relief depicting Ardashīr, Ahura Mazda presents the ribboned crown, a symbol of kingship, to Ardashīr in Firuz Abad. The relief bears a political message; the depiction of crown and commanding right or the kingship ringlet abdication by the God as a nearly mysterious manifestation without which ruling was impossible in Iran, Ardashīr legitimizes his attainment of power (Kurtis, 2010: 54 \& 55). 


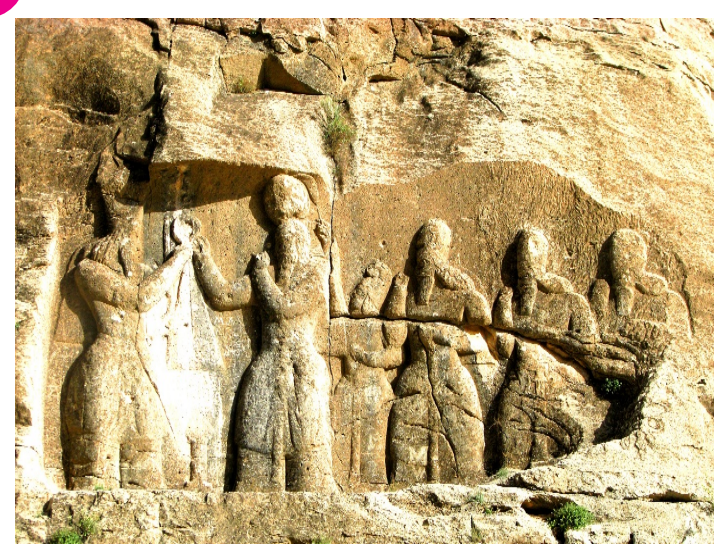

Figure 2. (fa.wikipedia.org)

7. The concept of unribboned rings in Salmas reliefs (image 3) cannot be considered as a manifestation of godly splendor and a symbol of God's representativeness on earth rather it conceptualizes the ringlet of victory an example of which can be seen in a relief displaying Shapur's victory over Roman emperors. In this inscription, a roman soldier has an unribboned ring in his hands stretched towards Shapur (Musavi Haji, 1995: 242).
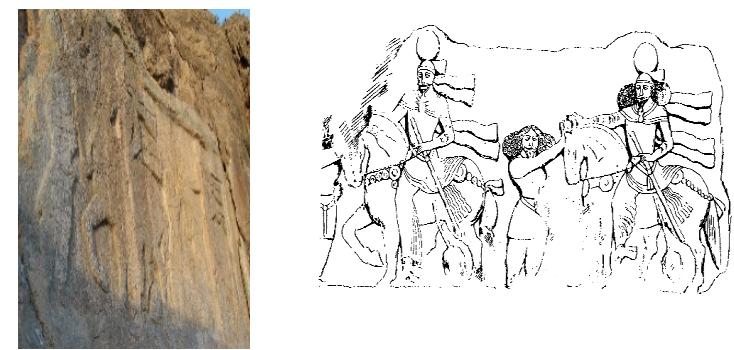

Figure 3. (Mohammadifar and Amini, 2015: 229)

8. Parthian and Sassanid kings did their best to show that their kingship and sultanate are divine because they needed legitimization of their kingship to have their objectives and intentions accomplished and such a legitimacy could only be created via showing the unity of religion and sultanate and this was continued to the extent that the kings introduced themselves as a successor of the gods' generation and/or unified with the religion. The manifestation of such a theory can be clearly seen in the inscriptions remaining from Sassanid era in which the kings give themselves epithets speaking of the divinity of their sultanate such as Shapur I inscription in Haji Abad wherein the king introduces himself as Mazda-worshipping goddess King Shapur, the king of Iran and an angel successor of the goddesses (Arthur Christine, 1935: 133).

\section{Introduction}

Some preliminary theories have been taken as principles due to the prominence of the theorizing researcher and precedence and the forthcoming theories are hence to be based thereon. The axiom is considered as a turning point by the researchers and it is no longer debated while it might be radically erroneous and this same problem also holds for the subject of the present study in such a way that a symbolic meaning (like sultanate ring) might have been expressed by an antecedent researcher(s) and formed the basis of the latecoming researchers' interpretation. The ring shown in the reliefs has been shown bearing a semantic and symbolic load (power and sultanate) following which it has been presumed as the ring of power and ring of sultanate by all the others and/or, put differently, the scenes have been rendered explicable in case that the ring is considered as a ring of power and a divine object. In author's idea, this cannot be the accurate interpretation of the scene and it can only be a justification for the defining of the scene. Thus, the author knows it necessary to subject the theory that is currently envisioned as a principle to criticism. The present study analyzes various semantic aspects of these symbolic rings. Additionally, the semantic load and use case of the rings have also been exposited in regard of all scenes displayed on the extant containers, coins, seals and reliefs herein.

\section{Study Theoretical Foundation}

Reality and imagination occasionally encounter in the various dramatic scenes and it is quite likely for the reality to most often become imaginary. In these scenes showing the image of the God within the cast of human body, the imagination has been transformed to reality to the extent that the delimitation between imagination and reality cannot be made. In fact, the reality part of the issue incorporates the people's beliefs and, most surely, beliefs and opinions do exist in the people but it has to be considered that the belief per se is an imaginary reality that is situated in the cultural continuity thereof (belief is the sub-construct of the imaginary scenes' realistic manifestation).

Art is attached in two branches to a specific definition. In one branch, it leads to reality and in another branch it is ended in imagination. Reality and imagination can be conflicting but they are both required for the creation of art and they influence one another. The art dealing only with reality is not an art and the art only engaging in imagination cannot be recounted an art and it cannot reach the degree of being described as an art. It is the balance between reality and imagination that can turn a scene into an art. Imagination should be objectified so as to create mentality because every mentality comes after objectification.

The depth of a scene, as the content thereof, 
cannot be perceived unless the surface is sufficiently understood. That is because the content is hidden beneath the surface and it can be found through reaching a conception of the surface semantic. The meaning and content expressed based on anything other than what is found on the scene's surface will be fake hence far away from the real truth and this provides one and the others with a false truth that is given the stance of a principle. Giving the ring the semantic load of power, sultanate or kingship upon the observation of a scene is definitely a false truth that is shown to be a principle.

Such problems may arise when a subject is taken as a presumption based on which a scene is explained. As such, the semantic load of the scene cannot be elucidated and even justified. That is where the researcher falls in the trap of his or her presumption and is forced to choose another presumption and change the meaning and the symbolic indication of the ring in such a way that the scene can be explained.

Semantically, the Ring of Victory is completely different from the Royal Ring that is a sign of the king's crowning. It is rather simplistic to take a ribbon as being influential on a ring in symbolic terms and then make the viewer consider it as the divinity indication. According to Dr. Musavi Haji, in Sassanid reliefs, the divinity of the king's position is embodied in the form of a ring that is gifted to the king by Ahura Mazda and sometimes by Anahita (Musavi Haji, 1995: 16).

The ring that is handed over by Ahura Mazda to the king cannot be reflective of the divinity of a position if it can be taken by the nonreligious and non-godly individuals in their hands and it becomes something completely earthly not supernatural, for example, the ring that is in the hands of the roman commander (image 4) and or other inscriptions that seem noteworthy in this regard whereas if the ring is to be given a semantic load of royalty then it is perfectly useless to give it other significations like power, victory and change its use case and this is a sort of disrespect to the religion and people's beliefs because the semantic load of the ring has been defined for the general public.
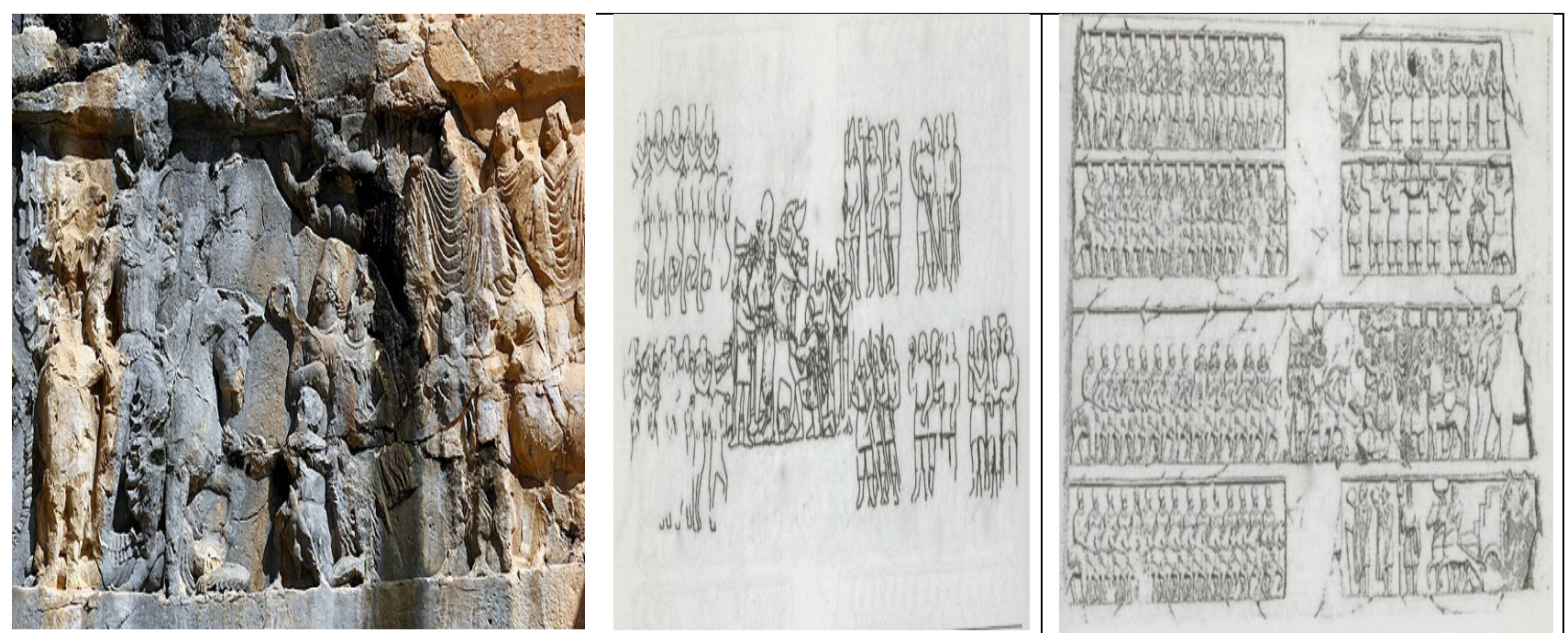

Figure 4. Mohammadifar and Amini (2015: 210)

The ring's being attached to a ribbon in some of the scenes appears to be serving a mere formality and aesthetical purpose. The creation of scenes on the reliefs and other inscriptions wherein a ring attached with a ribbon is shown only serves formality purposes and there are other reliefs showing the king in clothing and makeup decorated with ribbons. It is worth mentioning that even the embodiment of Ahura Mazda and/or the goddess in a human form perfectly serves formality purposes.

The aforementioned ring possesses one semantic load and one symbol only. The semantic load expresses in every period of history and in every scene the content of the relief and the meaning of the scene.

Dr. Musavi Haji points out in regard of Sassanid
Era's reliefs that "the divinity of the king's position in the Sassanid era's reliefs used to be objectified in the form of a ring gifted by Ahura Mazda and Anahita, in one case, to the Sassanid king. The most distinct feature of the ring is a ribbon hung thereof" (Musavi Haji, 1995: 241).

The Sassanid King gains a godly rank through receiving an object from the God!!! There are questions raised in regard of the issue:

1) How can it be shown that the God has presented the king with the ring?

2) Why has it not been considered that the ring has been offered by the king to the God?

Note: the questions should be answered with no presupposition as to the ring is a divine object hence it could have not been offered by a man to the God. 
The researcher should seminally be looking for a way to prove the principle then come to accept it as a general axiom. The act of moving on with a presumption and then reaching an axiom based thereon can be presumably true but the presumption still remains to be proved. These questions can be answered when the scene is first brought to the eyes and eventually understood. It is in this case that an insight can be gained over the content of a scene.

John Kurtis has a point in regard of the essence of the action in in one outstanding Sassanid era relief and it seems to the author of the present article that it is accurately to the underlying truth of the issue: in a scene displaying Ahura Mazda or Hormoz's granting of the crown to Ardashīr I while riding on a horse in Rustam Relief (image 2), Ardashīr links the present and the future and the government and the national religion in an instant in a succinct and very dynamic expression of his material and spiritual victory. In a symmetrical composition that is solidly balanced, the king finds himself in his instant of victory before the God. In this inscription, the king's accomplishment in the battlefield has been equaled to the godly victories in the spiritual front (John Kurtis, 2010; Shayakhmetova \& Chaklikova, 2018).

The equation of the God's performance to the king's performance in one front conveys the idea that the superiority has originated from the unification between the king and the God the consequences of which have given rise to the victory, solidification of the kingship and far deeper belief in the supernatural powers concealed in the format of the God or goddess in religion. Using a little scrutiny, this content and the entire contents of the other scenes underline one turning point that is formed, is forming or requested to be formed. That point is called unification.

The scenes or the reliefs and inscriptions can be expressed based on the author's classification as below:

1) Unification has been formed.

2) Unification is in the progress of being formed.

3) Unification request has been made.

The result of all the actions and performances can be traced into unification that is portrayed in every scene between two figures or personalities: the God and the king, the king and the satrap, the king and the defeated enemy, the king and the queen, the king and the successor, the goddess and the goddess and the God and the goddess. Of course, such unified governance has been exhibited via a personality in some of the scenes and this is indicative of absolute unification and emphasizes such an ideology.

\section{Conclusion}

According to the studies conducted by the author, the ring that is seen in various scenes from various historical eras in the hands of different personalities during a ceremony of a type cannot be ring of power, ring of kingship, crown of kingship and a sign of power abdication by a superior personality to an inferior one. Thus, numerous proofs are mentioned in the forthcoming parts to approve the aforesaid statement:

1) The first issue of a great importance is that it cannot be proved in any of these scenes and under any circumstances that which personality has granted which other personality the ring unless based on the certain presumptions as done by the researchers so far. For instance, the ring has been considered as a godly magnificence and its granting by an earthly figure like the king to an ethereal figure like Ahura Mazda is realized as improbable and contradictory to the beliefs and religiosity of the then time people. If the symbolism of the ring is changed, as a specimen consider it as a ring of victory, then, it will not be conflicting with the religiosity and beliefs of the people and it can be considered as gifted by an earthly figure to the God or a goddess. It is as if the ring symbolizing victory can rule a great many of the scenes and/or it can be gifted by any figure to any other figure if it happens to be changed in its use case. So, in lieu of trying to find a use case for the ring and impose it with a symbolic load before taking measures in line with understanding its real meaning, the ring's meaning and symbolic load should be determined according to the content of the scene otherwise an endless array of symbolization can be imposed and the scene can be easily justified.

2) The ring mentioned in the study is held in a hand between two earthly figures and it has nothing to do with religion, creed, God or goddess. The ring is held by the hand between two persons featuring given positions and names like Khask, satrap of Shush and Ardavan, the fifth, (the Parthian King) (image 5) and/or in Salmas Relief (image 3).

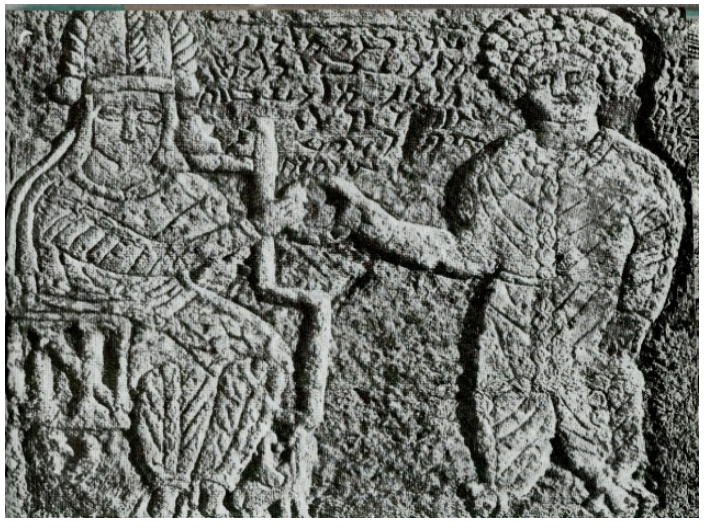


Figure 5. Ghirshman (1991: 56)

3) According to the studies carried out by such archaeologists as Musavi Haji, the ring has been categorized in two apparent forms: with a ribbon attached thereto and without ribbon. The ribboned ring is by no means held in the hands of two earthly figures and the emphasis is exclusively made on both of them, one earthly and one divine, and the ring with no ribbon is held in hands between two earthly figures and one of them has it grabbed in his hand stretched towards the other. So, it is generally held that the ring is definitely unribboned in case it is held between two earthly figures.

Unfortunately, some researchers make decisive conclusions based on their own field of view. An example of such conclusions is the following decisive classification: the coin of Jamasb, the Sassanid king (image 7) and/or the coin of Bahram II, the Sassanid king (image 6) on one side of which the king, the queen and the prince (Bahram III) have been portrayed. In this portray, the prince has a ring with various ribbons in his hand stretched towards the king and the queen. It is worth mentioning that the apparent shape of the ribbon differs in various coinages. It can be stated in regard of some coinages that the ribbon is sometimes longer and occasionally shorter and/or it is differently tied to the ring. The question is raised as to whether this person (prince) the personality of whom is clearly vivid should be considered as a divine figure for its holding of a ribboned ring in his hand or not? Or, is it not the case that the ribboned ring held by the prince in his hand poses contradiction of the established presumption?

It is postulated by some researchers that a ribbon should not be attached to the ring if it is held in hands between two earthly personalities. Looking sharper at the scene displaying Ahura Mazda and Ardashir I in Rustam Relief (image 2), it can be seen that Ardashir has not held the ring in his hand and he has only stretched his hand and it can be finally concluded that the person holding the ribboned ring in his hand is a divine figure and the king is standing in front of him without having his hand on the ring. This is completely matching the scene displayed on the coin of Bahram II (image 6 ) in which the prince has a ribboned ring in the hand stretched out towards the queen and the king who are standing right in front of him. There are numerous examples that can be expressed in this regard, including the seal (image 8) and Jamasb's coin (image 7) that can similarly discard the distortions. These comparisons easily prove that the ring has been mistakenly interpreted and distorted in its meaning by the researchers. This process could have been formed in two forms:
1) The semantic load has been given by the researchers to the ring hence it has been justified using the same method (previous researchers' style)

2) The content of the scene can be determined and the ring's semantic load can be perceived without imposing any distortion thereto. Then, it can form the basis of other interpretations as a presumption (author's method)

The ring's being attached to a ribbon or not does not seem to have any relationship with its being of an earthly or divine kind and the ribbon only serves ornamentation purposes and it is revealing of a formality state in some of the scenes.

Note: a principle and/or an axiom can hold when it is not endangered by any contradiction in case of the existence of which the axiom is rendered invalidated.
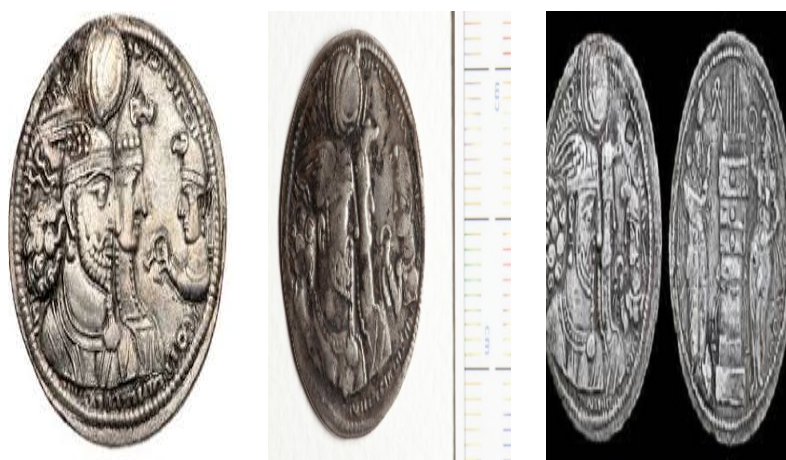

Figure 6. National Malek Library and Museum Institution (pinterest.com; sassanids.com

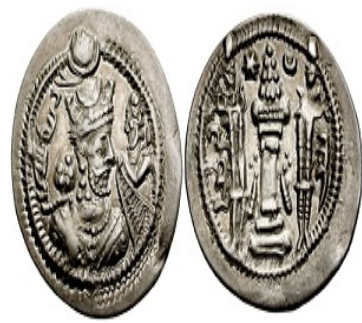

Figure 7. Ghirshman (1991: 232

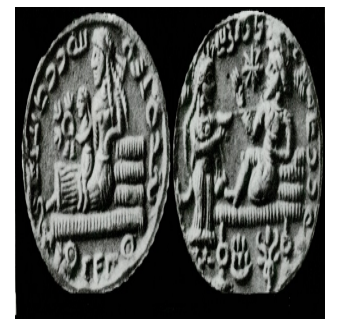

Figure 8.

pinterest.com
3) In a great many of the scenes, the unification ring is only in the hand of one personality such as in the hand of the goddess or the king and it essentially expressive of its symbol and there is no need for a counterpart so as to be interpreted based thereon.

4) The king or the goddess's holding of the ring does not indicate kingship. In a relief showing Rustam's victory (image 9), the king is seated on a throne. The supports of the throne are made in the form of eagles. The Zoroastrian priest is standing behind the king and the goddesses are sitting on the throne beside the king. All these specifications that can be found more or less in all the scenes of the reliefs and 
inscriptions point to the kingship and this dismisses the need for emphasizing on the ring as a symbol of power!!!? The semantic load of the ring unravels a meaning incorporating sultanate, religion and supernatural powers and creates an association between them. In other words, power, victory, stability, sultanate and others of the king are shadowed by the unification with the supernatural forces. Also, the unification between the earthly figures causes the solidification of the government and fulfilling the promises.
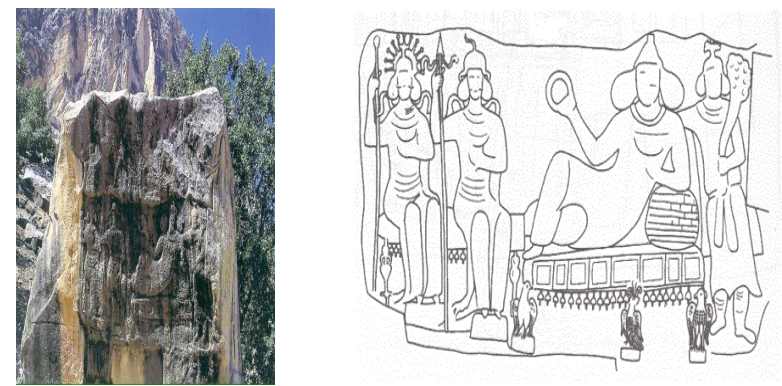

Figure 9. iranatlas.info

5) If the object extant in the scenes is to be a ring and be given a semantic and symbolic load, it has to be given a semantic load and symbol in all variegated scenes in such a manner that it finds a different semantic load according to the figures present on the scene and their positions. The explanation of the scene based on the ring's semantic load does not take place if it is so. Then, it can be stated in absolute terms that most of the scene justification will be based on the favorable symbol not explanation!!!

There is a ring shown in the reliefs on containers, inscriptions, seals, coins and so forth (images 10, 11, 12 and 13). Coins and containers could be moved to various geographical spots due to their being presented or traded and be exhibited to everyone. It is very much likely for such a special shape as a frequent part of the carvings in the reliefs to have been given a single meaning or symbol.

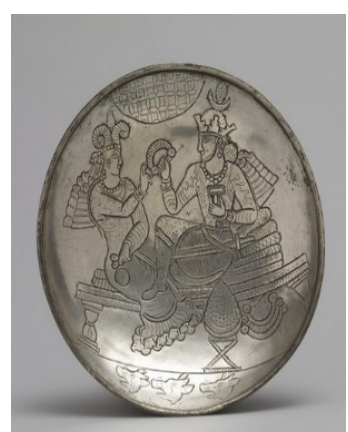

Figure 10. Ghirshman (1991: 218)

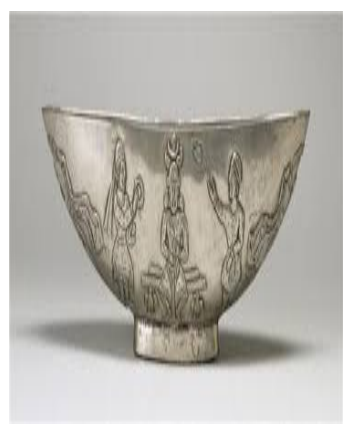

Figure 11. Serami (1994: 94); a silver container pertaining to Sassanid era (Baltimore Museum: object no.::

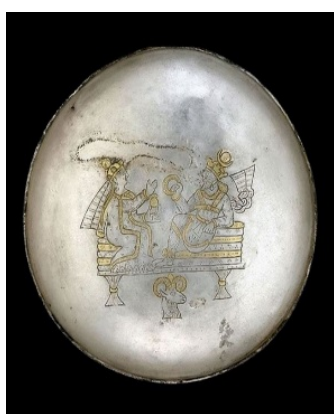

Figure 12.

pinterest.com
625: 57)

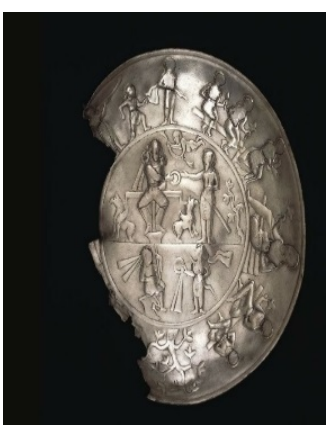

Figure 13.

pinterest.com

Note: the author underlines the idea that a special meaning can be generalized but a generalized meaning cannot be transformed to a special one. A special meaning can be turned into a general meaning but a general meaning cannot be rendered specific.

Surely, the ring has a common, special and defined semantic load which is unification as depicted in all the scenes.

6) The ring has been introduced in all of the scenes on the reliefs, containers, coins, ornamentations of buildings and decorations with semantic load of unification by means of which all the extant scenes can be explained and justified.

7) According to the fact that the shape of the ring exists in various temporal and kingship eras, the author is of the belief that it has entered Iran's culture from other cultures. So, it is suggested that the researchers had better try determining the roots of such an imprint of ring on reliefs from Parthian and Sassanid rings. Intercultural comparison can best serve this same purpose following which an insight can be gained over the issue. It is worth mentioning that the author still supports the perspective giving the ring a semantic load of unification for the other periods and cultures. The followings are Assyrians and Babylonians' seals and coins from Soluki era and, as it can be seen, the ring is present in all of them.

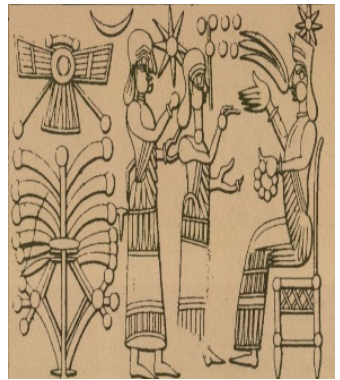

Figure 14. Lazar (2014: 115); explanation: a

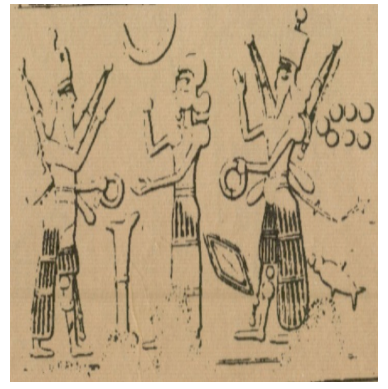

Figure 15. Lazar (2014: 116); explanation: cylindrical seal made of 
cylindrical seal

belonging to a

personal collection

owned by Sir William

Bugton, British museum

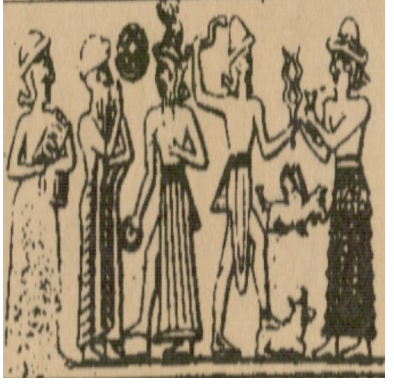

Figure 16. Lazar (2014: 117); explanation: the original copy was received from

London/anonymous owner and unknown material

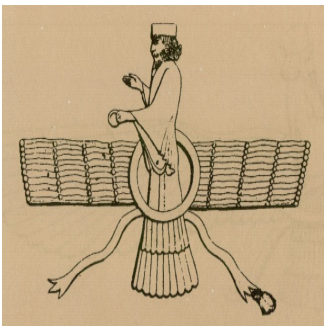

Figure 18. Lazar

(2014: 38);

explanation: a symbol of the Persian trinity

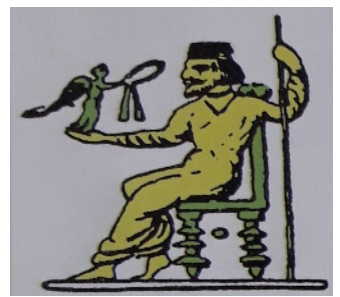

Figure 20. Amini

(2016: 75)

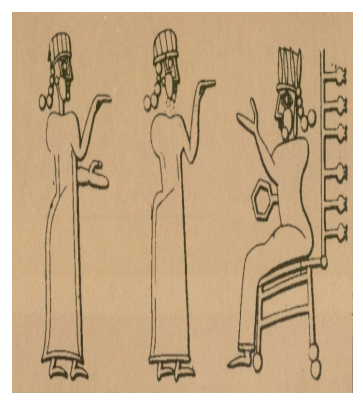

Figure 17. Lazar (2014: 115); explanation: cylindrical seal made of opal/British Museum

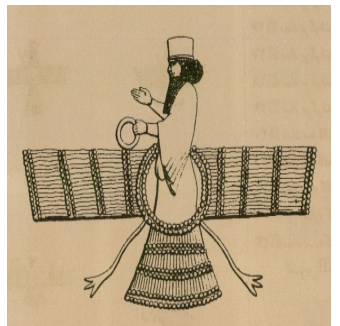

Figure 19. Lazar (2014: 38); explanation: a symbol of the Persian trinity/Rustam relief

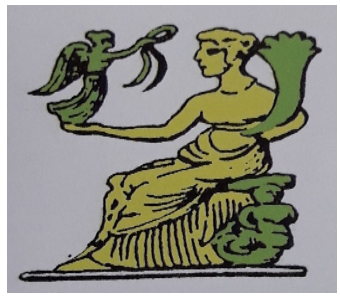

Figure 21. Amini (2016: 74)
Explanation of the scene 36: offering of the unification ring is indicative of the granting of the promise and allegiance of the personality holding the ring in his hand by the person standing in front of him or her.

Explanation of the scene 37: the offering of the unification ring is reflective of one's promise and allegiance granted by the person standing in front of him or her

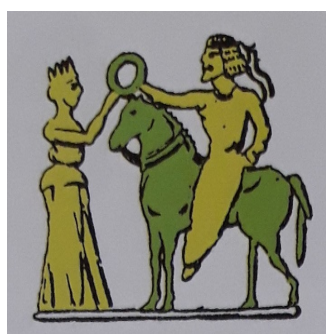

Figure 22. Amini (2016: 75); explanation: both figures have the ring in their hands as a sign of unification

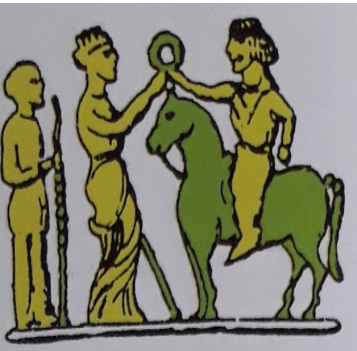

Figure 24. Amini (2016: 75)

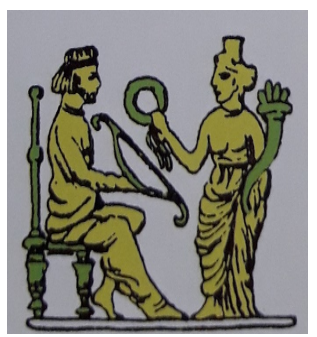

Figure 23. Amini

(2016: 74);

explanation: given by the female personality and the bow is presented by the male personality

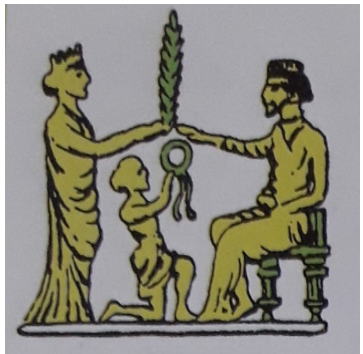

Figure 25. Amini

$(2016,75)$ unification ring is

Explanation of the image (43): both of the figures on the scene have the rings in their hands

Explanation of the image (44): the unification ring is held up by the person who is kneeling down while the hands of the male and female characters are joined by a branch. The person kneeling down requests unification and a sort of pact and treaty beneath the joined hands.

\section{References}

Arthur, Christiansen, (1935), "the status of the government and the royal court in Sassanid era", tr. Mojtaba Minavi, $1^{\text {st }}$ ed., Tehran, Teachings Commission press

Malekzadeh Bayani, Shahin, "sign of splendor", journal of historical investigations, $7(1)$

Sarfaraz, Ali Akbar, (1976), "discovery of important Sassanid era reliefs in Chowgan strait as reported in the fourth annual collection of archaeological discoveries and studies in Iran", under the supervision of Firuz Bagherzadeh, Tehran, Iran's archaeological center

Shahpour Shahbazi, Ali Reza, (2010), "the history of Sassanids", translation of Sassanid part from Tarikh-e-Tabari and comparing it with Tarikh-e-Bal'ami, Tehran, Amir Kabir

Kambakhshfard, Saifullah, (1995), "Kangavar's Ánahita Temple", Tehran, Cultural Heritage Organization 
Christiansen, Arthur, (2007), "Iran during Sassanids", tr. Rashid Yasemi, Tehran, Donyay-e-Ketab

Ghirshman, Roman, "Iran's art during Sassanids and Parthians' eras", tr. Bahram Farrehvashi, Tehran, scientific and cultural publication company

Luconin, Vladimire, (2005), "Sassanid Iran's civilization", tr. Enayatullah, Reza, $4^{\text {th }}$ ed., Tehran, Scientific and cultural publication center

Mohammadifar, Ya'aghub and Amini, Farhad, (2015), "Parthian archaeology and art", Tehran, Shapikan

Musavi Haji; Sayyed Rasoul, (1995), “a study of Sassanid reliefs", supervisor: Gholam Ali Hatam, teacher training university, human sciences university

Vandenberg, Luis, (2000), "ancient Iran archaeology, with an introduction by Roman Ghirshman", tr. Issa Behnam, Tehran, Tehran University press

Hertsfeld, Ernst, (2002), "Iran in ancient east", tr. Homayun San'atizadeh, Tehran, human sciences and cultural research center

Harper, Prudence, (2008), "Sassanid silver in Iran's history", v.3, part 2, Cambridge, supervised by Ehsan Shater Yar, tr. Hassan Anousheh, Tehran, Amir Kabir

Batist Fleix Lazar, Jean, (2012), "Mithraism secrets and days", tr. Sayyed Hassan Asefgah, Tehran, Tahoury

Serami, Rasoul, (1994), "investigating the Sassanids' silver containers in terms of their styles of manufacturing and ornamentation", supervisor, Susan Bayani, advisor, Akbar Sarfaraz, Teacher Training University, Tehran

Clledge Malcom A.R.1977. Parthian Art York, Ithaca.

-Agahirshman, R, 1952, Cing campagnes de fouilles a suse (1946-1951).Revue d assyriologie et d archeology orientale XLVI/1.

-Harper, P.O, 1979, Thrones and Enthronement Scenes in sasanian Art, Vol .17 .

-Herzfeld, E., 1924, paikuli, Berlin.

Herzfeld, E., 1927, Die Malereien von Sammarra, Berlin.

Herzfeld, E., 1934, A History of Ancient East. London and New York.Oxford university Press.

-Mosavi Haji ,Seyyed Rasool, reza Mehrafarin,2009, the Lade Represented in Narseh s Relief: Shapourdokhtak or Anahita?Intl.J.Humanities,vol.16(2)

H.Seyring , "Antiquites syriennes. Sur un bas-relief de Tang -i Sarvak",dans Syria, vol.XL VII, 1970.

R .Ghirshman .Iran .Parthes et Sassanides , 1962.

R .Ghirshman, "Terrasses Sacrees de Bard-e Nechandeh "T et mashid-I Solaiman"(=Memoires de la delegation Archeologique en Iran, vol. XLV) , vol.I,1976.
Shayakhmetova, D., \& Chaklikova, A. (2018). Development of the intermediator of intercultural communication based on public argumentative speech. Opción, 34(85-2), 149-185.

Courtney, S. A. (2018). Teacher EducatorEmbedded Professional Learning Model. International Electronic Journal of Mathematics Education, 13(3), 103-123. https://doi.org/10.12973/iejme/2702 